\title{
Peregrinatio in stabilitate: la transformación de un mapa de los Beatos en herramienta de peregrinación espiritual
}

\author{
Sandra SÁENZ-LóPEz PÉREZ \\ Para Serafín Moralejo Álvarez, in memoriam, \\ en agradecimiento por su inspiración
}

El mappamundi del manuscrito del Comentario al Apocalipsis de Beato de Liébana conservado en la Catedral de Burgo de Osma, Soria (Cod. 1, fols. 34v$35 \mathrm{r})^{1}$, no es solamente uno de los mapas más conocidos de la serie cartográfica de los Beatos, sino una de las ilustraciones artísticas de mayor interés para conocer la geografía religiosa altomedieval (fig. 1). Fue realizado posiblemente en Sahagún $^{2}$ en 1086, un año después de que Alfonso VI reconquistara Toledo ${ }^{3}$. En 1978, Luis Vázquez de $\mathrm{Parga}^{4}$ dio a conocer otro mappamundi muy semejante al de Burgo de Osma, que si no derivó de él, lo hizo de otro muy similar actualmente perdido (fig. 2). Se trata del que a partir de ahora conoceremos como mapa de Milán, por conservarse en la Biblioteca Ambrosiana de esta ciudad italiana (Ms. F. 105 SUP., fols. 71v-72r). Está inserto en un códice misceláneo posiblemente realizado en el scriptorium del monasterio cluniacense de San Salvador de Oña

1 Este manuscrito ha sido reproducido en facsímil en BEATO DE LiÉBANA, Expositio im Apocalisim, Valencia, 1992, 2 vols. El mejor estudio del mappamundi de Burgo de Osma se encuentra en el comentario crítico del facsímil: S. Moralejo Álvarez, "El Mundo y el Tiempo en el Mapa del Beato de Osma", op. cit., vol. 2, pp. 151-179; reed. en Patrimonio artístico de Galicia y otros estudios. Homenaje al Prof. Dr. Serafin Moralejo Álvarez, Santiago de Compostela, 2004, vol. 2, pp. 237-260.

2 Aunque no se conoce con seguridad el scriptorium en el que se realizó, la mayoría de los investigadores lo han vinculado a un monasterio leonés, y más concretamente a Sahagún. Según Timoteo Rojo, pudo pertenecer al monasterio de Santa María de Carracedo de la diócesis de Astorga, por la mención que figura en el fol. 165r. Véase T. Rojo, "El Beato de Burgo de Osma", Art Studies, 8 (1931), p. 123.

Es sin duda curioso destacar que el mapa de Burgo de Osma es el primero de los mappaemundi de los Beatos que incorpora Toledo; los restantes mapas previos a él omiten la ciudad, quizá porque cuando estos fueron realizados, y hasta 1085, estaba en manos musulmanas. Para la idea de la Reconquista cristiana de la Península Ibérica a través de la cartografía medieval, véase S. SÁENZ-LóPEz PÉrEz, "La Reconquista cartográfica: el Islam peninsular en la cartografía medieval hispana”, Treballs de la Societat Catalana de Geografia, 61-62 (2006), pp. 279-301.

4 L. VÁzquez de Parga, "Un mapa desconocido de la serie de los «Beatos»”, Actas del Simposio para el estudio de los códices del “Comentario al Apocalipsis” de Beato de Liébana, Madrid, 1978, vol. 1, pp. $273-278$. 


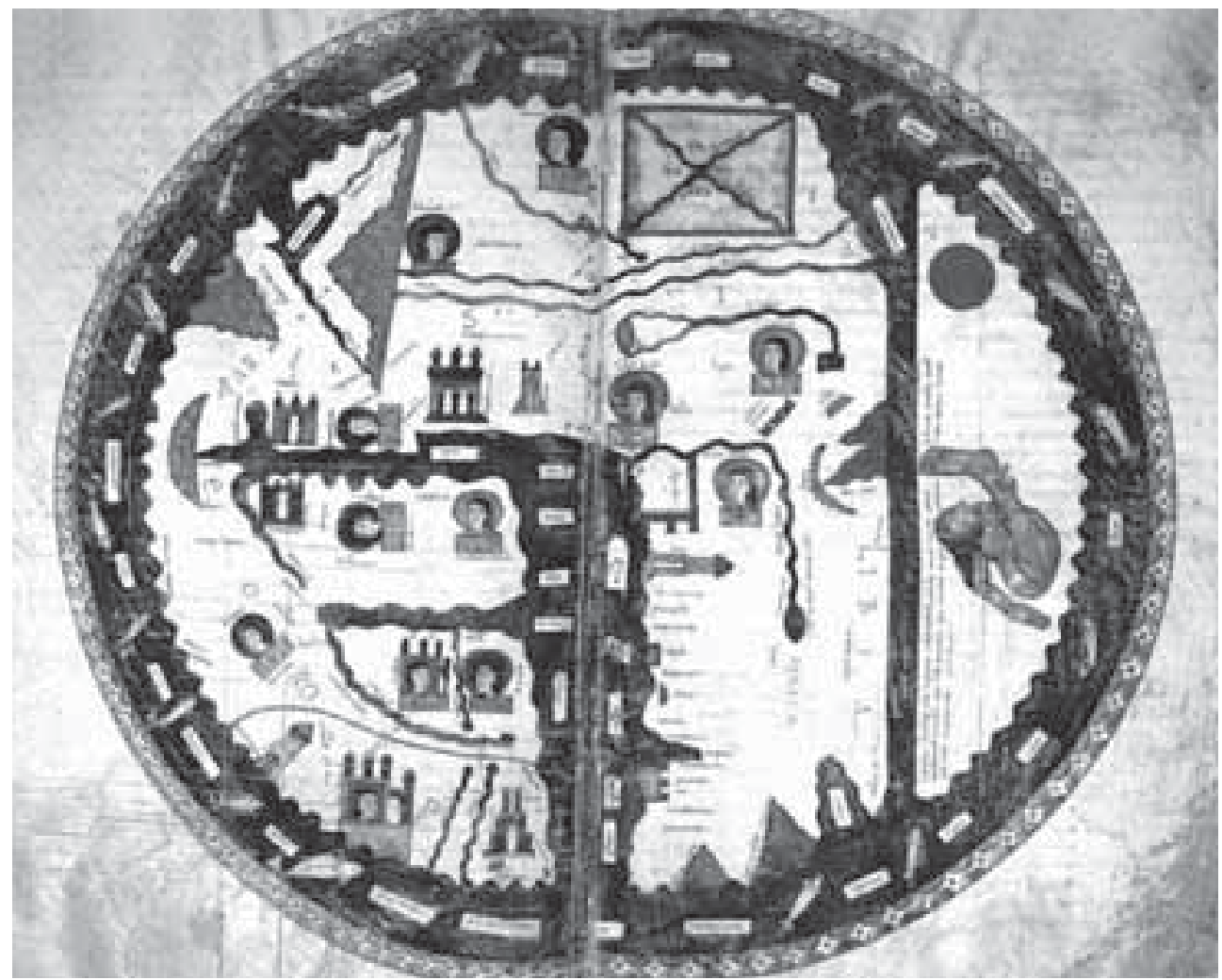

Fig. 1. Mapa de Burgo de Osma (1086). Soria, Catedral de Burgo de Osma (Cod. 1, fols. 34v-35r) (reproducción autorizada).

(Burgos) $^{5}$ a finales del siglo XII o principios del siglo XIII ${ }^{6}$. Desde que Luis Vázquez de Parga lo relacionara con los mappaemundi de los Beatos, poco se ha

5 L.A. Muratori reconoció este manuscrito como hispano en Rerum Italicarum Scriptores, Milano, 1726, II, ii, p. 1024; y Germain Morin lo adscribió al monasterio de San Salvador de Oña en 'Rainaud l'Eremite et Ives de Chartres: un épisode de la crise du cénobitisme au XI'-XII ${ }^{\mathrm{e}}$ siècle”, Revue Bénédictine, 40 (1928), pp. 100-101. El mappamundi parece corroborar este origen al representar el Río Ebro (Flumen Ibervs), que pasa por Oña, y que sin embargo no suele incorporarse en los mapas medievales. Es común dentro de la cartografía histórica el enfatizar en los mapas aspectos característicos del lugar de realización. Véase al respecto J.B. HARLEY, "Maps, Knowledge, and Power", D. Cosgrove y S. DANIELs (eds.), The Iconography of Landscape: Essays on the Symbolic Representation, Design and Use of Past Environments, Cambridge, 1988, p. 290. Para un ejemplo similar dentro de la cartografía de los Beatos, véase S. SÁENz-LóPEz Pérez, "Sobre el origen astorgano del Beato navarro: una rueda de molino para la imagen de Astorga de su mappamundi", en J.M. GARrido Aranda, et al. (eds.), Actas del $6^{\circ}$ Congreso Internacional de Molinología, 11 al 13 de octubre de 2007, Córdoba, Córdoba, 2008, pp. 175-186.

6 Para la datación de finales del siglo XII, véase L.A. Muratori, op. cit., p. 1024 y G. Morin, op. cit., pp. 100-101. Baudoin de Gaiffier sugirió extender la cronología a principios del siglo XIII a partir del análisis paleográfico y de la presencia y ausencia de determinadas fiestas en el calendario incorporado en este manuscrito, en "Un calendrier franco-hispanique de la fin du XIIe siècle", Analecta Bollandiana, 69 (1951), pp. 282-323. En el catálogo online de manuscritos de la Biblioteca Ambrosiana está fechado hacia 1201-1250. Véase la signatura "F 105 SUP" en <http://www.ambrosiana.eu/cataloghi/cataloghi_biblioteca.asp>. 


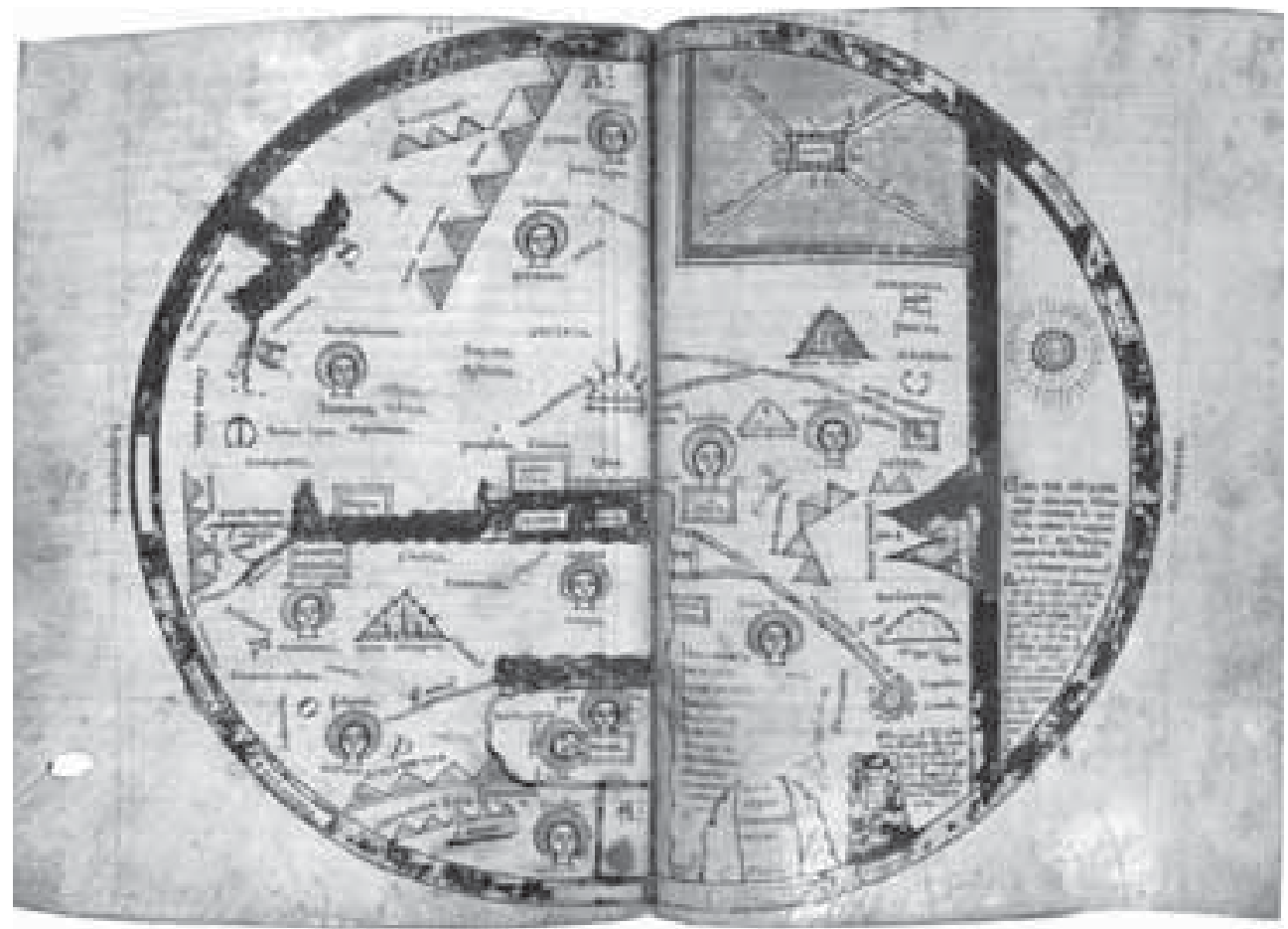

Fig. 2. Mapa de Milán (finales del siglo XII o principios del siglo XIII). Milán, Biblioteca Ambrosiana (Ms. F. 105 SUP., fols. 71v-72r) (reproducción autorizada).

escrito sobre él ${ }^{7}$, e indudablemente aún hay mucho que decir. Concretamente, es interesante conocer la razón por la que este mapa fue copiado en un manuscrito misceláneo, es decir, cuál era su finalidad, y si ciertamente es tan parecido a los mapas del Comentario al Apocalipsis de Beato de Liébana, y más concretamente al de Burgo de Osma, como parece a simple vista.

Según Luis Vázquez de Parga, el mapa de Milán comparte similitudes con el mapa del Beato de Escalada ${ }^{8}$-realizado probablemente en el monasterio de San

7 Véase J. Williams, "Isidore, Orosius and the Beatus Map", Imago Mundi. The International Journal for the History of Cartography, 49 (1997), p. 10; ID., The Illustrated Beatus. A Corpus of the Illustrations of the Commentary on the Apocalypse, vol. 1, Introduction, London, 1994, p. 164, nota 40; E. EDSon, Mapping Time and Space. How Medieval Mapmakers viewed their World, London, 1999, p. 153; B. EnGLISCH, Ordo orbis terrae. Die Weltsicht in den Mappae mundi des frühen und hohen Mittelalters, Berlin, 2002, pp. 334-344; e I. BAumgärTnER, "Visualisierte Weltenräume. Tradition und Innovation in den Weltkarten der Beatustradition des 10. bis 13. Jahrhunderts", H.-J. ScHMIDT (ed.), Tradition, Innovation, Invention. Fortschrittsverweigerung und Fortschrittsbewußtsein im Mittelalter, Berlin; New York, 2005, pp. 248-250. J. Chocheyras recurrió a este mapa para ilustrar un artículo, pero sin llevar a cabo ningún análisis concreto del mismo, en "Fin des Terres et Fin des Temps. D'Hésychius (Ve siècle) à Béatus (VIIIe siècle)”, W. Verbeke, D. Verhelst y A. Welkenhuysen (eds.), The use and abuse of eschatology in the Middle Ages, Leuven (Belgium) 1988, pp. 80-81.

8 New York, Pierpont Morgan Library (Ms. M. 644, fols. 33v-34r). Este manuscrito ha sido reproducido 
Salvador de Tábara (Zamora) a mediados del siglo $\mathrm{X}^{9}$, para el monasterio de San Miguel de Escalada (León)- y con el ya mencionado mapa de Burgo de Osma. La relación que este investigador establece entre los mappaemundi de Milán y Escalada debe ser sin embargo revisada, pues el nexo en común que afirma existe entre estos dos mapas radica solamente en algunos topónimos: de los treinta topónimos de Milán que no aparecen en Burgo de Osma, unos diez sí lo hacen en Escalada. No considero que la coincidencia de algunos topónimos sea suficiente para establecer esta vinculación; salvo unos nombres, poco más tienen en común, ni desde el punto de vista artístico, ni en lo que respecta a los textos incorporados en los mapas. Frente a esto, es interesante señalar que el cotejo del mapa de Milán con los restantes mappaemundi de los Beatos revela que los topónimos del mapa de Milán que no están presentes en el de Burgo de Osma, aparecen también en otros mapas, concretamente en Saint-Sever (tercer cuarto del siglo XI) ${ }^{10}$, Navarra (finales del siglo XII $)^{11}$ y Lorvão (1189) ${ }^{12}$-tres mapas que junto con Burgo de Osma integran la familia cartográfica I estudiada por Konrad Miller ${ }^{13} \mathrm{y}$ posteriormente por otros investigadores como Gonzalo Menéndez-Pidal ${ }^{14}-$. Resulta pues más probable que el mapa de Milán dependiera de los mapas de esta familia que del de Escalada, el cual pertenece a la familia IIa.

Las semejanzas entre el mapa de Milán y el de Burgo de Osma son mucho más numerosas y evidentes. Por ejemplo, en ambos mapas el mundo presenta forma circular; el Paraíso Terrenal, localizado en Asia, en la parte superior del mapa, está ilustrado con los cuatro ríos (Tigris, Éufrates, Geón y Fisón), que inscritos en un rectángulo, dispuestos en forma de "X", fluyen de una fuente central; Europa y

en facsímil en Beato de LiéBana, El Beato de San Miguel de Escalada: manuscrito 644 de la Pierpont Morgan Library de Nueva York..., Madrid, 1991, e ID., Apocalipsis de San Juan, Valencia, 2000-2001, 3 vols.

9 Los investigadores no se ponen de acuerdo en la datación de este manuscrito: Manuel Gómez-Moreno lo fechó en 926 en Iglesias Mozárabes. Arte español de los siglos IX a XI, Granada, 1975, p. 362; John Williams hacia 940-945 en op. cit., (1994), pp. 26-27; Sheila P. Wolfe hacia mediados o principios de la segunda mitad del siglo X en "The Early Morgan Beatus (M644): Problems of its place in the Beatus pictorial tradition", Tesis Doctoral, The Ohio State University, 1988, p. 152 y Peter K. Klein entre 950 y 960 en Der ältere Beatus-Kodex Vitr. 14-1 der Biblioteca Nacional zu Madrid. Studien zur Beatus Illustration und der spanischen Buchmalerei des 10. Jahrhunderts, 2 vols., Hildesheim; New York, 1976, vol. 1, pp. 280-283.

${ }_{10}$ Paris, Bibliothèque Nationale de France (Ms. Lat. 8878, fols. 45 bisv-45 ter). Este manuscrito ha sido reproducido en facsímil en Beato de LiéBana, Comentario al Apocalipsis y al Libro de Daniel, Madrid, 1984, 2 vols.

${ }_{11}$ Paris, Bibliothèque Nationale de France (Ms. nouv. acq. lat. 1366, ff. 24v-25). Este manuscrito ha sido reproducido en facsímil en E. Ruiz García y S. De Silva y VerÁstegui, Beato de Navarra (ms. nouv. acq. Lat. 1366 de la Bibliothèque Nationale de France), Madrid, 2007, 2 vols.

12 Lisboa, Arquivo Nacional da Torre do Tombo (Ms. CXIII/247, fol. 34bisv). Este manuscrito ha sido reproducido en facsímil en Beato de Liébana, Beato de Liébana: Códice de San Mamede de Lorvao, Valencia, 2003.

${ }_{13}$ K. Miller, Mappaemundi: Die ältesten Welkarten, vol. 1, Die Welkarte des Beatus, Stuttgart, 1895, pp. 24-27.

14 G. MenÉndez-Pidal, "Mozárabes y asturianos en la cultura de la Alta Edad Media en relación especial con la historia de los conocimientos geográficos", Boletín de la Real Academia de la Historia, 134 (1954), pp. 222-269; y posteriormente S. SÁEnz-López Pérez, Los mapas de los Beatos: la revelación del mundo en la Edad Media, Burgos, Editorial Siloé, 2012 (en prensa). 
África están en la parte inferior del mapa, separadas por el Mar Mediterráneo; al sur de la ecúmene encontramos la denominada "cuarta parte del mundo", en la que luce un gran sol para mostrar sus condiciones climáticas adversas; el Mar Rojo está pintado del color de su nombre y representado en forma de "M", para ilustrar la Península del Sinaí; y por último, las cabezas de los doce apóstoles aparecen esparcidas por todo el mundo, y en las mismas ubicaciones, desde Santiago el Mayor en Compostela -en el extremo más occidental del mundo conocido- a Santo Tomás en la India. Son especialmente los retratos esquemáticos y convencionales de los apóstoles los que revelan la factura artística románica de ambos mappaemundi.

El propósito de los mapas de los Beatos está aludido en el texto del propio Comentario al Apocalipsis. Su finalidad es la de ilustrar la Missio apostolorum, es decir, la evangelización de los apóstoles a todas las naciones, siguiendo el mandato de Cristo. Así por ejemplo, según Mateo $(16,15)$, tras su Resurrección, Cristo se apareció a los apóstoles y les dijo: "Id por todo el mundo y predicad el evangelio a toda criatura". En el Comentario al Apocalipsis de Beato de Liébana, en el texto que precede al mapa, se asigna a cada uno de los apóstoles un lugar a evangelizar:

Estos son los doce discípulos de Cristo, predicadores de la fe y doctores de los pueblos. Los Apóstoles, aunque todos sean uno solo, sin embargo cada uno de ellos recibió su propio destino para predicar en el mundo.

Pedro en Roma;

Andrés en Acaya;

Tomás en la India;

Santiago en España;

Juan en Asia $^{15}$;

Mateo en Macedonia;

Felipe en las Galias;

Bartolomé en Licaonia;

Simón Zelotes en Egipto;

Matías en Judea;

Santiago, hermano del Señor, en Jerusalén.

A Pablo no se le asigna una zona propia, como a los restantes Apóstoles, porque es elegido maestro y predicador de todos los pueblos gentiles ${ }^{16}$.

El texto continúa haciendo referencia a los apóstoles y concluye diciendo subiecta formula picturarum demonstrat, es decir, "la siguiente disposición de imágenes

${ }^{15}$ El lugar de predicación del apóstol San Juan es Asia, provincia romana de Asia Menor, y no el continente asiático.

16 J. González Echegaray, et al., Beato de Liébana, Obras Completas y Complementarias, Edición Bilingüe, Madrid, 2004, vol. 1, pp. 135 y 137. 
muestra" ${ }^{17}$. El mapa representa, pues, la evangelización apostólica, y con esta finalidad se incluye en el Comentario al Apocalipsis. Cabe ahora preguntarse de qué forma se evocaría el contenido del texto en las representaciones cartográficas. Una posible manera sería a través de la incorporación de los lugares asignados a los apóstoles para evangelizar: Roma, Acaya, India, España, Asia, Macedonia, las Galias, Licaonia, Egipto, Judea y Jerusalén. De hecho, así ocurre, por ejemplo, en el mappamundi de Escalada, que es el más antiguo de los Beatos conservado ${ }^{18}$, aunque fruto de la revisión que experimentó el Comentario al Apocalipsis de Beato de Liébana hacia el $940^{19}$.

Sin embargo, curiosamente no ocurre lo mismo en el mapa de Burgo de Osma, donde además, las cabezas de los apóstoles no siempre figuran en el lugar asignado en el texto, sino más bien donde fueron martirizados o donde se veneran sus restos. Por ejemplo, Santiago el Mayor aparece en Galicia (Gallecia), y no en España (Spania), y Pablo en Roma, aunque el texto no le asigna un lugar concreto. Según Carlos Cid Priego, la incorporación de las cabezas de los apóstoles en los mapas de los Beatos pone de relieve una evolución dentro de este corpus cartográfico, en el que se pasa de mostrar la geografía de la evangelización (que encontramos en Escalada), a descubrir la geografía de las peregrinaciones ${ }^{20}$. Serafín Moralejo Álvarez avaló esta idea, e identificó los retratos de los apóstoles con sus bustos-relicario ${ }^{21}$.

Una vez analizada brevemente la finalidad de los mappaemundi de los Beatos en el seno del Comentario al Apocalipsis, debemos plantearnos cuál fue el propósito del mapa de Milán. Al margen de esta imagen, el manuscrito misceláneo en el que se incluye no presenta ninguna otra ilustración ${ }^{22}$, ni ningún otro texto del Comentario al Apocalipsis de Beato de Liébana. Más aún, es interesante señalar que el mapa carece de relación alguna con las restantes obras del manuscrito. Por ello, podemos afirmar que el mapa de Milán fue copiado a partir de un mappamundi de un Beato como una obra absolutamente independiente.

El contenido de este manuscrito es muy variado ${ }^{23}$, pero la impresión general es que fue planteado como una compilación de cuestiones de carácter ético. Entre los

${ }^{17}$ La alusión al mapa en el propio texto de la obra ha servido para justificar que el Comentario al Apocalipsis original de Beato de Liébana (776-784) ya incluía esta representación.

${ }_{18}$ No se conserva ningún manuscrito del Comentario al Apocalipsis de Beato de Liébana anterior al de Escalada; el fragmento de la Biblioteca del Monasterio de Santo Domingo de Silos (frag. 4) está sin embargo fechado en la segunda mitad del siglo IX.

19 Véase J. Williams, "The Beatus Commentaries and Spanish Bible Illustrations", Actas del simposio para el estudio de los códices del 'Comentario al Apocalipsis'de Beato de Liébana, Madrid, 1978, vol. 2, pp. 201-219, esp. 213-219.

20 C. Cid Priego, "Santiago el Mayor en el texto y en las miniaturas de los códices del Beato", Compostellanum, 10:4 (1965), pp. 264-265.

${ }_{21}$ S. Moralejo Álvarez, op. cit., p. 159.

22 Salvo dos esquemáticas representaciones de las zonas climáticas y los cuatro elementos en el fol. 8v, para ilustrar el texto de las "Tabula Pascualis et notae astronomicae".

${ }_{23}$ Véase Inventario ceruti dei manoscritti Della Biblioteca Ambrosiana, B Sup-I Sup, Milano, 1977, vol. 3, pp. 490-492; y el catálogo online de manuscritos de la Biblioteca Ambrosiana (véase nota 6). 
trabajos de esta naturaleza podemos citar, por ejemplo, Qualiter vivere debeant qui Christum imitari desiderant ["Cómo deben vivir los que quieren imitar a Cristo"] (fol. 20r); De abstinentia ["Sobre la abstinencia"] de San Jerónimo (fol. 35v); Quae sunt instrumenta bonorum operum ["Cuáles son los instrumentos de las buenas obras"] de San Benito (ca. 480-543) (fol. 52v); De regulis perseverandi in vita spirituali ["Sobre las reglas para perseverar en la vida espiritual"] del abad Paphnutius (?) (fol. 53r); De contemptu mundi Carmina Leonina ["La canción Leonina sobre el desprecio del mundo"] (fol. 87r); y Ascetica et theologica plura ex variis ["Extractos de varios autores sobre ascética y teología"] (fol. 99r). El mappamundi está descrito en el catálogo de la Biblioteca Ambrosiana como Mappa mundi designans loca martyrii apostolorum, es decir, "Mappamundi que muestra los lugares de martirio de los apóstoles". Sin embargo, un análisis del mapa en profundidad y el carácter general de las obras encuadernadas con él parecen sugerir que el propósito del mapa no fue ni el de explicar la Missio apostolorum, ni el mostrar los lugares de peregrinación de los apóstoles, ni aquellos en los que fueron martirizados. Posiblemente fue utilizado como una herramienta para la peregrinatio in stabilitate ${ }^{24}$. Con este mapa, desde el encierro del monasterio, supuestamente de San Salvador de Oña, los monjes podían llevar a cabo peregrinaciones espirituales, deambular por el mundo cristianizado e ir a Tierra Santa o incluso visitar santuarios como el de Santiago de Compostela.

La finalidad del mapa de Milán, tan distinta del propósito de los mappaemundi de los Beatos, parece confirmarse a partir de las diferencias encontradas entre este mapa y su semejante, el de Burgo de Osma (fig. 3). El aspecto más interesante radica en que el cartógrafo del mapa de Milán señaló no solamente las regiones evangelizadas por los apóstoles, sino también otros lugares sagrados en Tierra Santa, convertidos en importantes destinos de peregrinación. Además de "Jerusalén" (Iherusalem), representada al igual que en el mapa de Burgo de Osma con la cabeza del apóstol Santiago el Menor, encontramos en Milán otros topónimos como "Nazaret" (Nazarech), "Belén" (Bechlem) y "Galilea" (Galilea). Estos lugares fueron muy importantes en la vida de Cristo y, por ello, en la historia de la cristiandad. Galilea es la tierra en la que Cristo comenzó a predicar y donde se encuentran tanto Belén, cuna de $\mathrm{Cristo}^{25}$, y Nazaret, donde la Virgen María recibió el anuncio del arcángel San Gabriel ${ }^{26}$, y donde Cristo vivió hasta el comienzo de su vida pública a la edad de 30 años. Sin embargo, a pesar de su importancia como centros religiosos, no aparecen en ninguno de los mappaemundi del Comentario al Apocalipsis ${ }^{27}$.

24 Peregrinatio in stabilitate es un término acuñado por Jean LeClercq para referirse a los ejercicios espirituales permitidos a los monjes para que, sin salir de su encierro, pudieran llevar a cabo peregrinaciones y visitar los santos lugares. Véase J. LECLERCQ, "Monachisme et peregrination du IXe au XIIe siècle", Studia Monastica, 3 (1961), pp. 33-52.

25 Mateo 2; Lucas 2.

26 Lucas 1, 26 ss.

27 Galilea aparece como "Galilea inferior" y "Galilea superior” en el mapa de Saint-Sever; sin embargo, ninguno de los otros dos, ni Belén, ni Nazaret, están presentes, a pesar de ser el mapa de los Beatos que más 


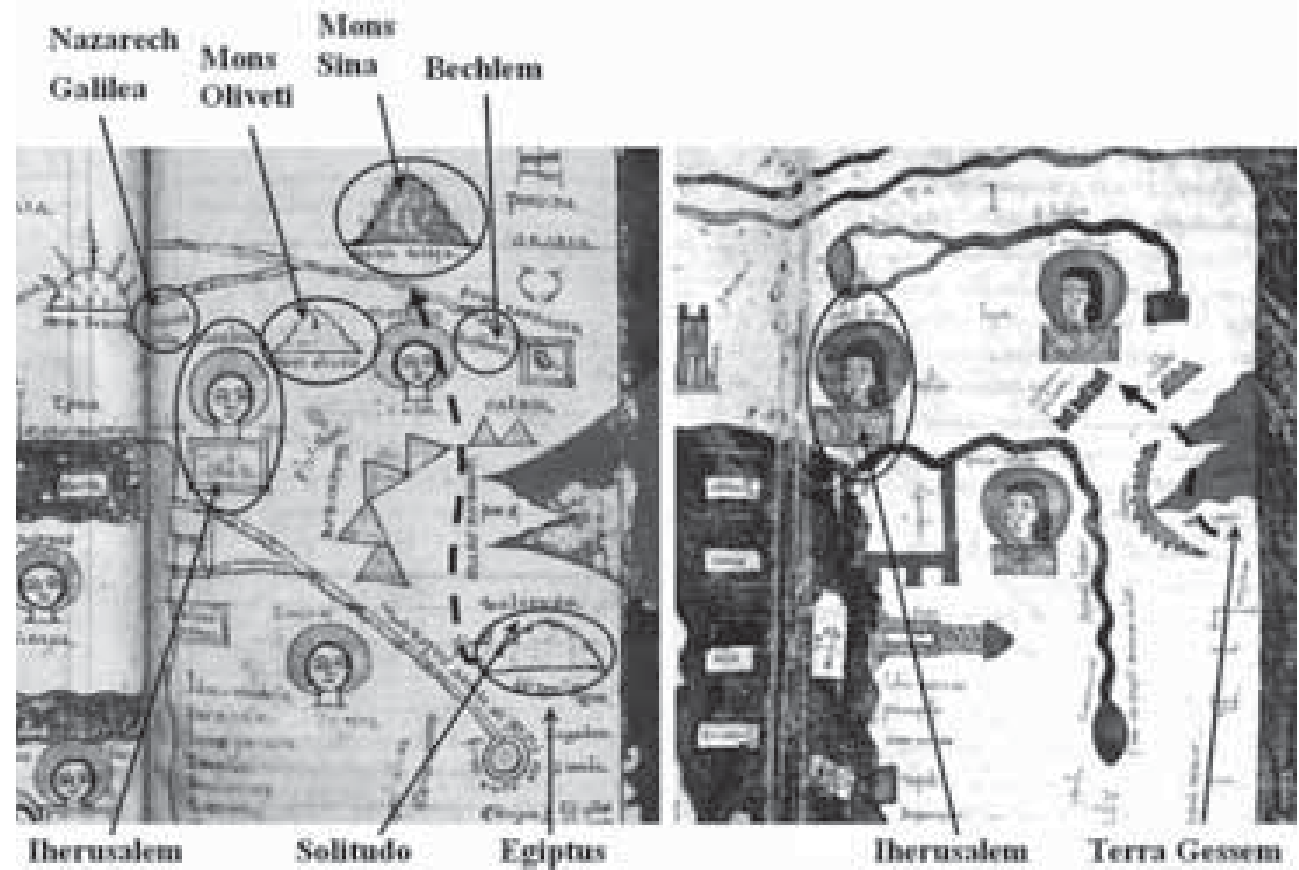

Fig. 3. Comparación de Tierra Santa en los mapas de Milán y Burgo de Osma, que revela una mayor riqueza religiosa en el primero (reproducción autorizada).

Además de estos topónimos, el mapa de Milán muestra junto a Jerusalén el "Monte de los Olivos" (Mons Oliveti). Esta referencia geográfica tampoco figura en los mappaemundi de los Beatos. Su inclusión en el mapa de Milán se debe a su importancia religiosa: este fue el lugar en el que Cristo rezó y sufrió por los pecados del mundo la noche previa a su crucifixión. Otra montaña igualmente sagrada es el "Monte Sinaí" (Mons Sina). En dicha montaña Dios entregó las Tablas de la Ley a Moisés, quien guiaba al Pueblo de Israel en su éxodo de Egipto hacia la Tierra Prometida. Asimismo, es interesante apreciar que no solamente está representada dicha montaña, sino que podemos trazar todo el Éxodo sobre el mapa de Milán ${ }^{28}$, desde Egipto hasta Tierra Santa atravesando el Mar Rojo; en el "Desierto" (Desertvm) apreciamos una separación en la cadena de montañas a modo de paso del pueblo de Israel. Este último detalle aparece también en el mapa de Burgo de Osma, donde junto al Mar Rojo encontramos el topónimo "Tierra de Jesé" (Terra Gessem) aludiendo probablemente a la región en la que los israelitas permanecie-

topónimos incorpora. Para la toponimia de los Beatos véase K. Miller, op. cit.; y H. GarcíA-ArÁEz Ferrer, "Los Mapamundis de los Beatos (2 $2^{a}$ parte). Nomenclator y conclusiones", Miscelánea Medieval Murciana, XIX-XX (1995-1996), pp. 97-128.

28 El Éxodo de los israelitas está referido textualmente en el mapa de Saint-Sever: "Desertum ubi filii Israel XL annis errauerunt" y "Transitus filiorum Israel”, en K. MiLleR, op. cit., p. 52. 
ron como esclavos del faraón ${ }^{29}$, hasta que fueron liberados por Moisés y llevados hacia la Tierra Prometida ${ }^{30}$. No obstante, el Monte Sinaí, una de las paradas fundamentales en la Historia del Éxodo, no está representado en este mapa.

Por último, Egipto, en el mapa de Milán, debería entenderse no solo como el lugar de partida del Pueblo de Israel. Dentro del cristianismo, el desierto egipcio es un lugar históricamente sagrado donde muchos santos eremitas y ascetas se retiraron a vivir, por ejemplo, San Pablo y San Antonio Abad (mediados del siglo III a mediados del siglo IV). La montaña representada en el mapa está acompañada de la inscripción "Soledad" (Solitvdo), que puede entenderse como una alusión no tanto a la idea de desierto físico, sino de aislamiento ascético ${ }^{31}$, de la misma forma que el desierto se define en la Biblia, por ejemplo, en Deuteronomio $(32,10)$, donde se dice: "Lo halló en tierra de desierto, / en yermo de horrible soledad".

La realización de peregrinaciones espirituales a lugares sagrados, especialmente a Jerusalén, se convirtió en una práctica relativamente común en la Edad Media. Estos viajes imaginarios podían emprenderse a través de ejercicios de meditación, que generalmente consistían en la lectura de un texto o la contemplación de una imagen, así como mediante actividades físicas que consistían en deambular recreando el viaje religioso, pero a miles de kilómetros del lugar sagrado - por ejemplo, utilizando los laberintos pavimentales góticos, como el de la Catedral de Amiens realizado en 1288 (actualmente copia del siglo XIX), que conducían a un centro identificado con Jerusalén (fig. 4)-. A través de estas peregrinaciones imaginarias, los peregrinos no solamente recibían consuelo espiritual, sino también indulgencias, sin necesidad de exponerse a ningún peligro o gasto económico ${ }^{32}$. Aunque los ejemplos de peregrinaciones espirituales que conocemos son en su mayoría de finales de la Edad Media,

29 Génesis, 47.

30 Éxodo, 13.

31 Du Cange interpreta Solitudo en el sentido de desierto, en Glossarium Mediae et Infimae Latinitatis, Paris, 1846, t. VI, s.v. "Solitudo", p. 291. Danielle Lecoq, sin embargo, lo entiende como aislamiento ascético en "Place et fonction du désert dans la représentation du monde au Moyen Âge", Revue des Sciences Humaines, 258 (2000), p. 15. Para el simbolismo del desierto véase J. Le Goff, "Le désert-forêt dans l'Occident medieval", Un autre Moyen Age, Paris, 1999, pp. 495-510; y B. McGinN, "Ocean and desert as symbols of mystical absorption in the Christian tradition”, Journal of Religion, 74:2 (1994), pp. 155-181.

32 Para algunos ejemplos de peregrinaciones espirituales llevadas a cabo en la Edad Media, y las herramientas necesarias para ello, véase J. Sumption, Pilgrimage: an image of mediaeval religion, Totowa (New Jersey) 1975, pp. 300-301; J.K. Hyde, "Italian Pilgrim Literature in the Late Middle Ages", Bulletin of the John Rylands University Library of Manchester, 72:3 (1990), pp. 13-33, esp. 22; C. GARGIOLli (ed.), Viaggi in Terra Santa di Lionardo Frescobaldi e d'altri del secolo XIV, Firenze, 1862, p. 441, para el "Viaggio in Terra Santa di un anonimo"; K.M. Rudy, "Den aflaet der heiliger stat Jherusalem ende des berchs van Calvarien: Indulgenced Prayers for Mental Holy Land Pilgrimage in Manuscripts from the St. Agnes Convent in Maaseik", Ons geestelijk erf, 74:3 (2000), pp. 211-254; ID., "A Guide to Mental Pilgrimage: Paris, Bibliothèque de 1'Arsenal Ms. 212”, Zeitschrift für Kunstgeschichte, 63:4 (2000), pp. 494-515; ID., “A Pilgrim's Book of Hours: Stockholm Royal Library A233”, Studies in Iconography, 21 (2000), pp. 237-277; ID., “Addendum”, Studies in Iconography, 22 (2001), pp. 163-164; y M.L. Ehrenschwendtner, "Virtual Pilgrimages? Enclosure and the Practice of Piety at St Katherine's Convent, Augsburg", The Journal of Ecclesiastical History, 60:1 (2009), pp. 45-73. 


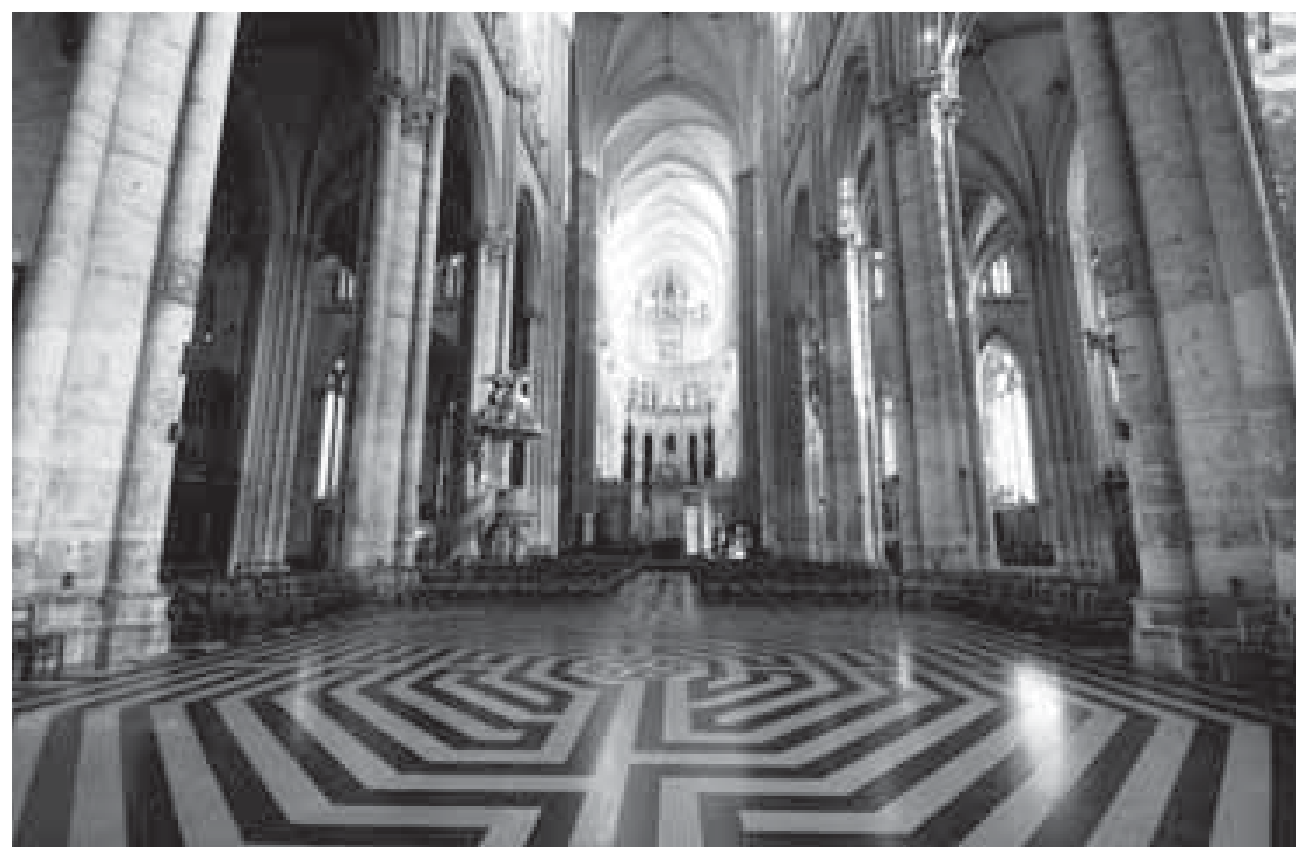

Fig. 4. Laberinto pavimental de la Catedral de Amiens (copia del siglo XIX del original de 1288) utilizado para recrear peregrinaciones a Jerusalén (foto de la autora).

según afirma Daniel Connolly, estas prácticas estaban ya arraigadas en el ámbito monacal en los siglos XII y XIII. Añade este investigador que no tenemos numerosos documentos que prueben su existencia de forma evidente debido a que inicialmente las peregrinaciones espirituales se emprendían a través de la ayuda de imágenes, y no tanto mediante la lectura de textos ${ }^{33}$. Como Giles Constable ha puesto de relieve, muchos escritores medievales se alzaron contra la salida de los monjes en peregrinación $^{34}$, e incluso la Regla de San Benito de Nursia (ca. 480-547), en su capítulo 4:78, imponía al monje la realización de las buenas obras "en la clausura del monasterio donde uno ha de perseverar estable en la comunidad"35. La peregrinatio in stabilitate adquirió pues un especial valor dentro del ámbito monástico, ya que estos viajes imaginarios eran en muchos casos la única forma que tenían los monjes de visitar los santos lugares, y asimismo, la única vía de escape a su enclaustramiento, a la "prisión"

${ }^{33}$ D. Connolly, "Imagined Pilgrimage in Gothic Art: Maps, Manuscripts and Labyrinths", Tesis Doctoral, University of Chicago, 1998, p. 2.

${ }^{34}$ Véase G. Constable, "Opposition to Pilgrimage in the Middle Ages", Mélanges G. Fransen I. Studia Gratiana, 19 (1976), pp. 125-146; e ID., "Monaschisme et pèlegrinage au Moyen Age”, Revue Historique, 258 (1977), pp. 3-27.

35 A. Linage Conde, La regla de San Benito: ordenada por materias, y su vida, en el español corriente de hoy, Sepúlveda, 1989, p. 45. 
en la que se convertía el claustro ${ }^{36}$. El mapa de Milán, concebido como herramienta de peregrinación espiritual, sería pues, una ventana abierta al mundo.

En la Edad Media cristiana, la geografía y la cartografía estaban dotadas de un sensus spiritualis, es decir, de un sentido espiritual ${ }^{37}$, muy especialmente dentro de los monasterios. Algunos mapas medievales han sido reconocidos por distintos investigadores como imágenes a través de las cuales los monjes podían llevar a cabo peregrinaciones imaginarias, y el mapa de Milán debe ser ubicado dentro de este corpus cartográfico. A él, según Daniel Connolly ${ }^{38}$ y Michael Gaudio ${ }^{39}$, pertenece, por ejemplo, el mapa de la Chronica majora de Matthew Paris realizado en la abadía benedictina de St. Albans, Inglaterra, hacia $1250^{40}$. El mapa representa el itinerario de Londres a Jerusalén a través de caminos que, a modo de calles verticales, unen las distintas paradas del viaje ilustradas con símbolos arquitectónicos.

Otro ejemplo es el mappamundi de Hereford (1300), realizado por Richard de Haldingham probablemente en Lincoln, y trasladado posteriormente a la Catedral de Hereford (Reino Unido), donde se conserva en la actualidad ${ }^{41}$. Se trata de un gran mapa de forma circular en el que Jerusalén aparece en el centro del mundo. Según Daniel Connolly, esta ciudad es la meta hacia la cual el observador medieval se orientaría con la vista ${ }^{42}$. A diferencia del itinerario de Matthew Paris, en el $m a$ ppamundi de Hereford los caminos de peregrinación espiritual no resultan evidentes. El mapa está completamente cubierto de imágenes y leyendas derivadas de la historia bíblica, antigua y medieval, representadas y escritas para ser vistas y leídas desde diferentes ángulos, en algunos casos de lado, o incluso de forma invertida. Posiblemente, los caminos del mapa no serían rectos, sino sinuosos.

La representación del Éxodo en este mapa parece arrojar alguna luz sobre esta forma de peregrinar (fig. 5). Dicho viaje aparece señalado a través de una línea que conecta los acontecimientos más importantes acaecidos desde la salida de Egipto del pueblo de

36 Para el sentido del claustrum como "prisión", y otras acepciones que este término adoptó en la Edad Media, véase P. Meyvaert, "The Medieval Monastic Claustrum”, Gesta, 12:1/2 (1973), pp. 53-59.

37 Magriet Hoogvliet menciona numerosos ejemplos en los que se pone de relieve el sensus spiritualis de la geografía y la cartografía medieval en Pictura et scriptura: textes, images et herméneutiques des Mappae mundi, XIIIe - XVIe siècles, Turnhout, 2007, pp. 248-255.

38 D. Connolly, "Imagined Pilgrimage in the Itinerary Maps of Matthew Paris", The Art Bulletin, 81:4 (1999), pp. 598-622 -este artículo es una revisión del cap. 2 de su Tesis Doctoral (véase nota 33)-. Véase también su publicación más reciente sobre este mapa The Maps of Matthew Paris: Medieval Journeys through Space, Time and Liturgy, Woodbridge, 2009.

39 M. Gaudio, "Matthew Paris and the Cartography of the Margins", Gesta, 39:1 (2000), pp. 50-57.

40 Parker Library of Cambridge, Corpus Christi College (Ms. 26, fols. 2r-4r). Para los mapas de Matthew Paris véase S. Lewis, "Imagines Mundi: Matthew's Cartography”, The Art of Matthew Paris in the Chronica Majora, Berkeley, 1987, pp. 321-376.

41 Para este mappamundi véase S.D. Westrem, The Hereford Map, Turnhout, 2001; y los distintos artículos contenidos en P.D.A. HARveY, The Hereford world map: medieval world maps and their context, London, 2006.

42 D. Connolly, op. cit., (1998), p. 222. 


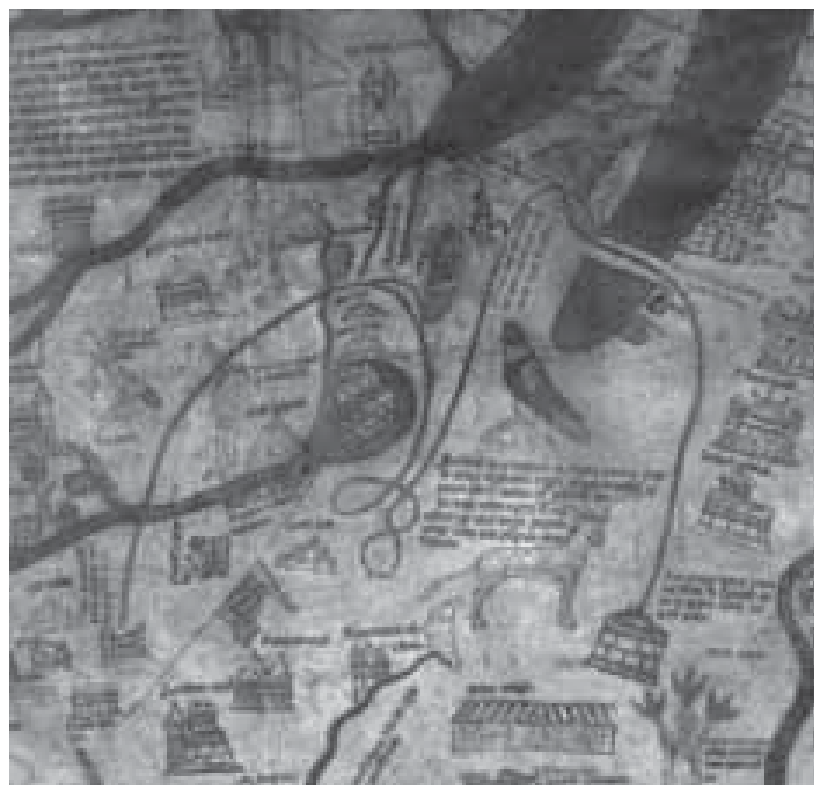

Fig. 5. Detalle del mappamundi de Hereford (ca. 1300) con la representación del Éxodo del Pueblo de Israel y los lugares de peregrinación en Tierra Santa. Cathedral of Hereford (reproducción autorizada).
Israel hasta su llegada a la Tierra Prometida, en orden cronológico y geográfico. Este recorrido es sinuoso, realiza numerosos giros, lo que posiblemente trataba recrear de forma simbólica el deambular por el desierto del Sinaí ${ }^{43}$. Por lo que respecta a la idea de la peregrinación espiritual con el mapa, es interesante apreciar que en la recreación mental del viaje del Éxodo, el observador no solamente revive los acontecimientos bíblicos, sino que también visita algunos de los lugares a los que los peregrinos solían acudir en su visita a Tierra Santa. Entre las fuentes empleadas para la realización de este mapa, George R. Crone identificó el uso de itinerarios de peregrinación ${ }^{44}$, con lo que es obvio pensar que el mappamundi de Hereford permitiera recrear la experiencia de peregrinar. Uno de los ejemplos más interesantes es el objeto representado en el Monte Sinaí, junto a la figura de Moisés, quien, tocado con cuernos ${ }^{45}$ y arrodillado, está a punto de recibir las Tablas de la Ley entregadas por la Mano de Dios que asoma de unas nubes alusivas al cielo. Dicho objeto, en forma de sarcófago con un una cruz latina sobre su tapa, parece aludir a las reliquias de Santa Catalina ${ }^{46}$; según la leyenda, tras ser martirizada en Alejandría, unos ángeles traslada-

43 También es sinuoso el recorrido que Naomi Reed Kline reconstruyó del viaje de Alejandro Magno en el mappamundi de Hereford, en "Alexander interpreted on the Hereford Mappamundi", P.D.A. HARVEY, op . cit., p. 168, fig. 1. No obstante, esta autora afirma al respecto que "an attempt to follow Alexander's eastern campaign on the Hereford map indicates the obvious difficulty of following the sites on the map as itinerary and argues for a different way of reading this material", en ibid., p. 167.

44 G.R. CRone, "New Light on the Hereford Map", The Geographical Journal, 131:4 (1965), pp. $447-$ 460, esp. 453, donde menciona la influencia del Camino a Santiago de Compostela en el mappamundi de Hereford. John Hamer afirma que "the names and order of cities presented in the map could be used by pilgrims to reach Santiago de Compostela as well as other lesser pilgrimage sites", en J. Hamer, "The Hereford Mappamundi As the Embodiment of a Medieval World-View', The Thetean (1992), p. 76.

45 Los cuernos de la cabeza de Moisés son una alusión iconográfica a que, al bajar del Monte Sinaí con las Tablas de la Ley, la piel de su rostro se había vuelto radiante por haber hablado con Dios (Éxodo 34:29-35). Para la explicación iconográfica de Moisés con cuernos véase R. Mellinkoff, The Horned Moses in Medieval Art and Thought, Berkeley, 1970.

46 S.D. WeStREM, op. cit., p. 120. 
ron su cuerpo hasta ese monte, y allí se construyó el monasterio que lleva su nombre, convertido en un lugar de afluencia de peregrinos ${ }^{47}$. Otros lugares localizados en el mapa y visitados en peregrinaciones a Tierra Santa son el Monte Horeb ${ }^{48}$-la montaña en la Península del Sinaí en la que Dios estableció un pacto con Moisés (Deuteronomio 5, 1-2)-, y el Mar Muerto, al cual se asignaban curiosas propiedades ${ }^{49}$.

Todos los caminos de peregrinación a Jerusalén en el mappamundi de Hereford son invisibles a nuestros ojos, pero quizá no lo eran para el observador medieval. Esta idea deriva del estudio de otro mapa semejante, el mappamundi de Ebstorf (ca. $1300)^{50}$ (fig. 6). Fue realizado en Alemania, pero a instancias de Gervase de Tilbury, lo que explica sus conexiones inglesas tan claras ${ }^{51}$. Al igual que el mappamundi de Hereford, Ebstorf es circular con Jerusalén en el centro, quizá también en este caso destino de las peregrinaciones espirituales llevadas a cabo con él. Un texto en el ángulo superior derecho menciona el uso del mappamundi de Ebstorf para viajar, y la existencia de direcciones y rutas: "Puede verse que [esta obra] es de no poca utilidad para sus lectores, ofreciendo direcciones a los viajeros, y un gran deleite en la contemplación de las cosas a lo largo de las distintas rutas" ${ }^{92}$.

Debido a su enorme tamaño -358 x $356 \mathrm{~cm}$, siendo el mapa medieval más grande llegado a época moderna ${ }^{53}$ - los viajes que el texto sugiere debían ser sin duda imaginarios, pues no sería práctico el transportar el mapa de un lugar a otro ${ }^{54}$. Y las "direcciones" y "distintas rutas" ofrecidas en el mapa, son nuevamente, al igual que en el mappamundi de Hereford, invisibles a nuestros ojos.

Otro ejemplo de un mapa medieval empleado para peregrinaciones espirituales es el contenido en un manuscrito misceláneo de finales del siglo $\mathrm{XV}$, realizado en

47 En relación con la leyenda del traslado del cuerpo de Santa Catalina al Monte Sinaí y la veneración de sus restos, véase C. WALSH, The cult of St Katherine of Alexandria in early Medieval Europe, Aldershot, 2007, pp. 39-46; y N.P. ŠEvČEnKo, "St. Catherine of Alexandria and Mount Sinai", P. Armstrong (ed.), Ritual and art: Byzantine essays for Christopher Walter, London, 2006, pp. 129-143.

48 S.D. Westrem, op. cit., 170.

49 Ibid., p. 118.

50 Destruido en un bombardeo en 1943, solamente lo conocemos a través de sus reproducciones facsimilares, como la conservada en París, Bibliothèque Nationale de France (Ge AA 2177). Para una reproducción de este mapa véase H. Kugler, et al., Die Ebstorfer Weltkarte, Berlin, 2007, 2 vols. y las imágenes online $<$ http://classes.bnf.fr/ebstorf/><http://www.uni-lueneburg.de/uni/index.php?id=ebskart $>$ y $<$ http://12koerbe. de/henkaipan/mundus.htm>.

51 Para la autoría del mapa véase D. Woodward, "Medieval Mappaemundi", J.B. Harley y D. Woodward (eds.), Cartography in Prehistoric, Ancient, and Medieval Europe and the Mediterranean, Chicago; London, 1987, pp. 286-370, esp. 307; y P.D.A. HARvey, Medieval Maps, London, 1991, p. 25.

${ }_{52}$ Traducción de la autora. "Que scilicet non parvam prestat legentibus utilitatem, viantibus directionem rerumque viarum gratissime speculationis directionem”, en W. Rosien, Die Ebstorfer Weltkarte, Hanover, 1952 , p. 80.

53 Otro mappamundi mayor que el de Ebstorf se conoce solo a través de su contrato de realización. Véase R.A. Skelton, "A Contract for World Maps at Barcelona, 1399-1400”, Imago Mundi. The International Journal for the History of Cartography, 22 (1968), pp. 107-113, esp. 109.

54 E. Edson, The World Map, 1300-1492: The Persistence of Tradition and Transformation, Baltimore, 2007, p. 31. 


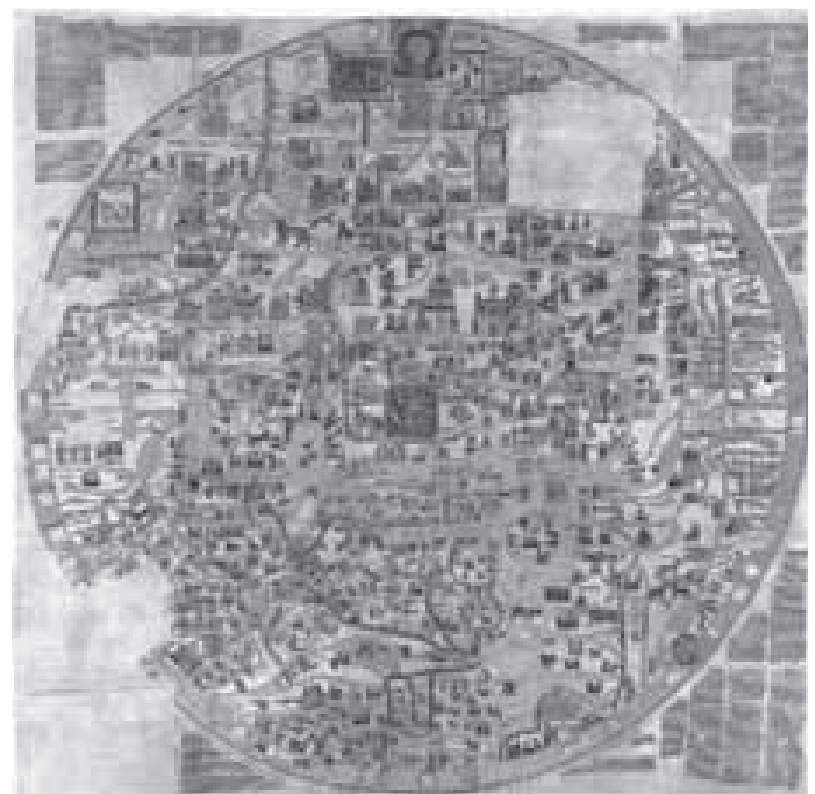

Fig. 6. Mappamundi de Ebstorf (ca. 1300) reproducido en facsímil en color; original perdido (reproducción autorizada). un monasterio cartujo del norte de Inglaterra ${ }^{55}$. El mapa fue interpretado por Andrea Kann como un plano o guía empleado por los monjes para la realización de peregrinaciones mentales ${ }^{56}$, idea que ha sido estudiada recientemente en mayor profundidad ${ }^{57}$. La existencia de otros mapas medievales empleados como herramientas de peregrinación espiritual contribuye a entender este mismo propósito en el caso del mapa de Milán. Aunque todos los mapas que cumplen esta finalidad son muy distintos entre sí, comparten como característica común la importancia concebida a Tierra Santa, algo que como veíamos se cumple en el mapa de Milán, a diferencia de lo que ocurre en los mappaemundi de los Beatos.

La idea del mapa de Milán como herramienta para la peregrinación espiritual se corrobora al estudiar otro mapa tipológicamente muy cercano a él. Se trata de nuevo de otro mapa muy similar, si no copia, del de Burgo de Osma. Sin embargo, en este caso el mapa no se reprodujo en pergamino, sino en la pared de un monasterio, concretamente en la capilla izquierda o capilla del Evangelio de la iglesia del monasterio de San Pedro de Rocas, en Ourense ${ }^{58}$ (fig. 7). El monasterio fue fundado en el siglo VI, siendo originariamente excavado en la roca de una colina. La pintura mural data de finales del siglo XII, y desgraciadamente se encuentra en muy mal estado de conservación. Entre los restos de policromía se pueden apreciar algunas de las ca-

55 London, British Library (Add. Ms. 37049, fol. 2v).

56 A. KanN, "Picturing the World: The Illustrated Manuscripts of The Book of John Mandeville", Tesis Doctoral, University of Iowa, 2002, pp. 68-84, esp. 69.

57 C. VAn Duzer y S. SÁEnz-LóPez Pérez, "Tres filii Noe diviserunt orbem post diluvium: The World Map in British Library Add. MS 37049”, Word \& Image, 26:1 (2010), pp. 21-39.

58 Este mappamundi fue estudiado en J.M. GARcía IgLESIAs, "El mapa de los Beatos en la pintura mural románica de San Pedro de Rocas (Orense)”, Archivos Leoneses, 69 (1981), pp. 73-87; y en mayor profundidad en S. Moralejo Álvarez, "El mapa de la diáspora apostólica en San Pedro de Rocas: notas para su interpretación y filiación en la tradición cartográfica de los Beatos”, Compostellanum, 31 (1986), pp. 315-340. Para reproducciones en color de los restos de este mapa véase A.M. Malingre Rodríguez, Monasterio de San Pedro de Rocas. Pisamos tierra de monjes, Trobajo del Camino (León), 2001, pp. 32-33. 
bezas de los apóstoles esparcidas por todo el mundo, de forma muy semejante al mappamundi de Burgo de Osma ${ }^{59}$. Por ejemplo, Pedro y junto a él tan solo visible la tonsura de Pablo, en Roma; y Simón en Egipto, junto al faro de Alejandría (figs. 8 y 9). La ubicación prominente del mural dentro de la iglesia y su gran tamaño $(200 \mathrm{~cm}$ x $220 \mathrm{~cm}$ ) confirman que el mapa desempeñó ciertamente una finalidad religiosa. Como ya sugirió anteriormente Serafín Moralejo Álvarez en su estudio, resulta natural considerar que los monjes de este monasterio lo concebirían como una herramienta para una peregri-

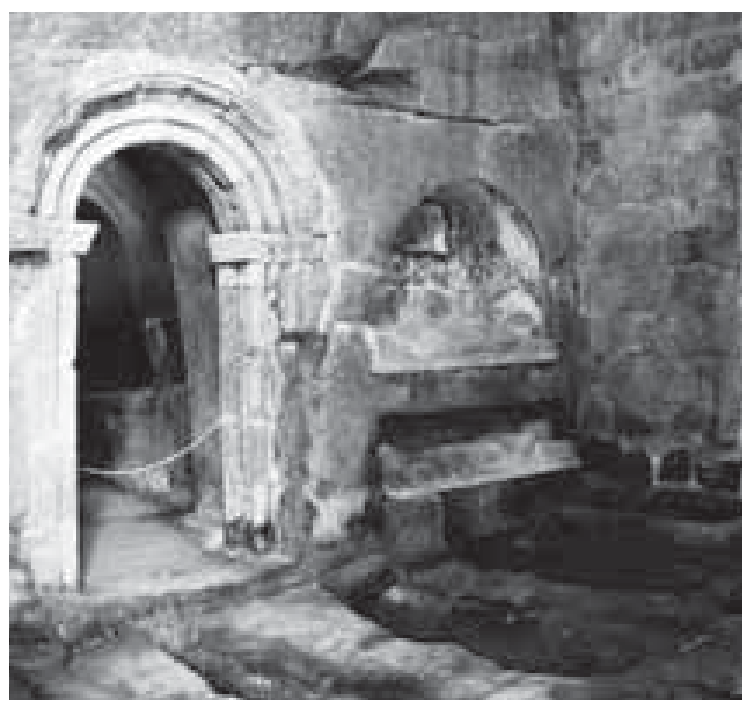

Fig. 7. Iglesia del monasterio de San Pedro de Rocas, Ourense (foto de la autora). nación imaginaria, especialmente teniendo en cuenta que San Pedro de Rocas era un eremitorio ${ }^{60}$. El mapa era pues su única vía para salir al mundo exterior.

Los mapas de Milán y San Pedro de Rocas constituyen dos ejemplos de la adaptación de un mapa de los Beatos a una nueva finalidad, concretamente la de herramientas de peregrinación espiritual a través de su contemplación. Al respecto, resulta sin duda curioso el pensar que dentro de la amplia variedad de mapas medievales, incluso de mapas que cumplían con esta misma finalidad, ambos mappaemundi-Milán y San Pedro de Rocas - se inspiraron en un mapa de los Beatos, concretamente en el mappamundi de Burgo de Osma u otro muy similar a él ${ }^{61}$. Resulta tentador plantear que las cabezas de los apóstoles harían de estos mapas no solo guías para peregrinar a

59 La vinculación de este mapa y el de Burgo de Osma podría derivar de la dependencia de ambos monasterios de la diócesis de Astorga; recordemos que según Timoteo Rojo, el mappamundi de Burgo de Osma pudo pertenecer al monasterio de Santa María de Carracedo, dependiente de dicha diócesis (véase nota 2), e igualmente, el monasterio de San Pedro de Rocas ha sido relacionado con la diócesis astorgana por su carácter eremita. Para la importancia del eremitismo dentro esta diócesis, véase A. QuINTANA, El Eremitismo en la Diócesis de Astorga, Pamplona, 1970; y G. CAVERo DomínguEz, "Eremitismo y emparedamiento en la Edad Media (Diócesis de Astorga)", VV.AA., El Monacato en la Diócesis de Astorga durante la Edad Media, Astorga, 15, 16 y 17 de diciembre de 1994, Actas del Congreso, Astorga, 1995, pp. 165-189.

60 Véase A.M. Malingre Rodríguez, San Pedro de Rocas, un eremitorio rupestre altomedieval, Ourense, 1995.

${ }_{61}$ Jacques Fontaine reconoce el valor espiritual que aportaba la contemplación de las imágenes del Comentario al Apocalipsis de Beato de Liébana, en J. Fontaine, "Fuentes y tradiciones paleocristianas en el método espiritual de Beato", Actas del Simposio para el estudio de los códices del 'Comentario al Apocalipsis' de Beato de Liébana, Madrid, 1978, vol. 1, pp. 75-101; quizá el "método espiritual contemplativo" de estas imágenes favoreció la elección uno de los mapas de los Beatos como modelo de otros mapas empleados para peregrinaciones espirituales. 


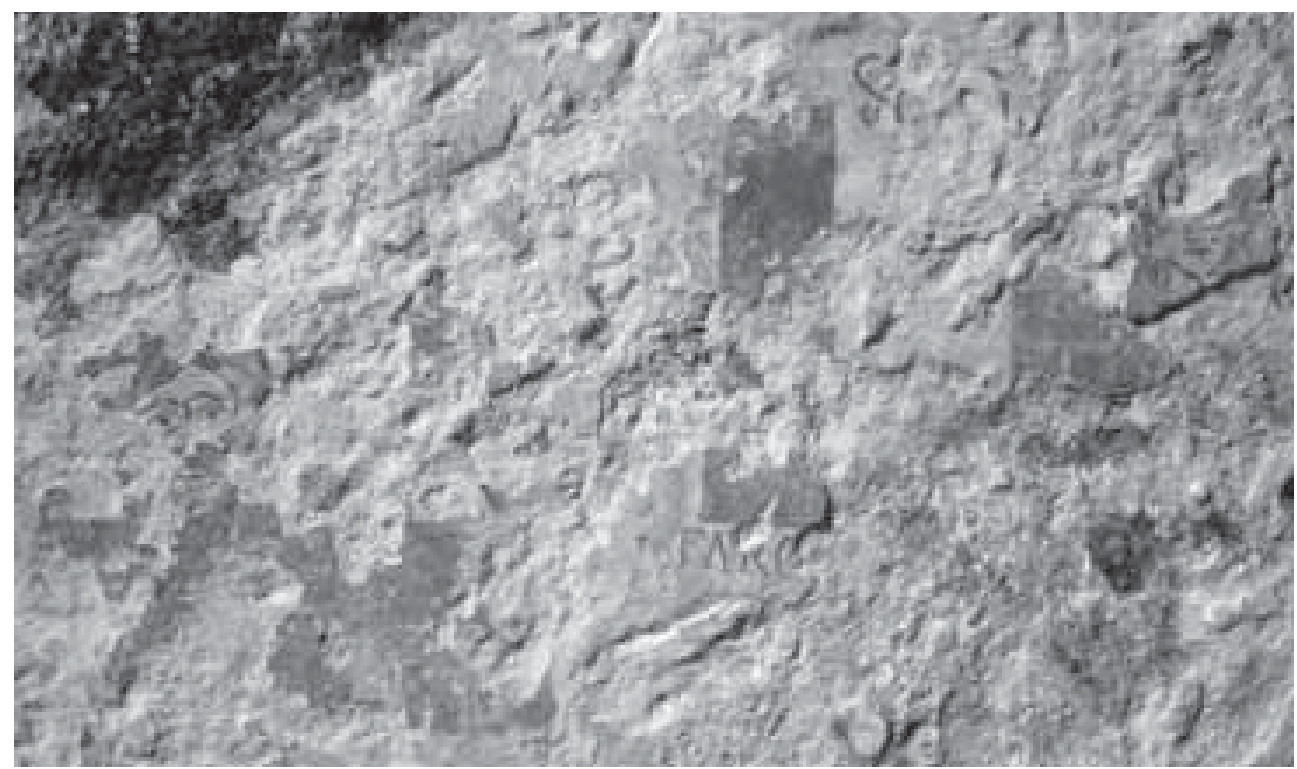

Fig. 8. Detalle del mapa mural de San Pedro de Rocas con las cabezas de Pedro y Pablo en Roma, y Simón en Egipto junto al faro de Alejandría (foto de la autora).

Jerusalén, sino también a otros lugares santos donde los apóstoles predicaron, fueron martirizados o enterrados, como Santiago de Compostela.

La idea de seguir a los apóstoles que estos mappaemundi parecen sugerir, está relacionada con el modelo espiritual conocido como vita apostolica, cuya meta era la de emular la forma de vida de Cristo, sus apóstoles y discípulos, según recoge el Evangelio $^{62}$. La vita apostolica como un modus vivendi se reforzó durante la reforma gregoriana (ca. 1050-1080) ${ }^{63}$, por lo que este modo de vida estaba ya establecido en el seno de las comunidades monásticas en el momento en que los mapas de Milán y San Pedro de Rocas fueron realizados. El deseo de imitar a los apóstoles llevaba a los monjes incluso a metafóricamente tratar de experimentar las gentes, los lugares y los acontecimientos de la época de estos, para así poder alcanzar una íntima unión con Cristo $^{64}$. Incluso la Regla de San Benito en su capítulo 48:8 invitaba a los monjes

62 Para la vita apostolica véase L.-M. Dewailly, "Notes sur l'histoire de l'adjectif 'apostolique"”, Mélanges de science religieuse (Lille), V (1948), pp. 141-152; E.W. McDonnell, "The "Vita Apostolica': Diversity or Dissent", Church History, 24:1 (1955), pp. 15-31; C. DereINE, "La 'Vita Apostolica' dans l'ordre canonial du IXe au XIe siècles", Revue Mabillon, 51 (1961), pp. 47-53; G. OLSEN, "The idea of the Ecclesia Primitiva in the Writings of the twelfth-century canonists", Traditio, 25 (1969), pp. 61-86; K.S. FrANK, "Vita Apostolica. Ansätze zur apostolischen Lebensform in der alten Kirche”, Zeitschrift für Kirchengeschichte, 82 (1971), pp. 145-166; y C. BYNUM, Docere verbo et exemplo: An Aspect of Twelfth-Century Spirituality, Missoula (MT), 1979, pp. 19-21.

${ }^{63}$ Véase G. BARDY, "Saint Grégoire VII et la réforme canoniale au XIème siècle", Studi Gregoriani, 1 (1947), pp. 47-64; y C. DEREINE, "Le problème de la vie commune chez les canonists, d'Anselme de Lucques à Gratien”, Studi Gregoriani per la storia, 3 (1948), pp. 287-298.

64 Véase M.-H. VICAIRE, L'imitation des apôtres: moines, chanoines, mendiants, IVe-XIIIe siècles, Paris, 1963. 


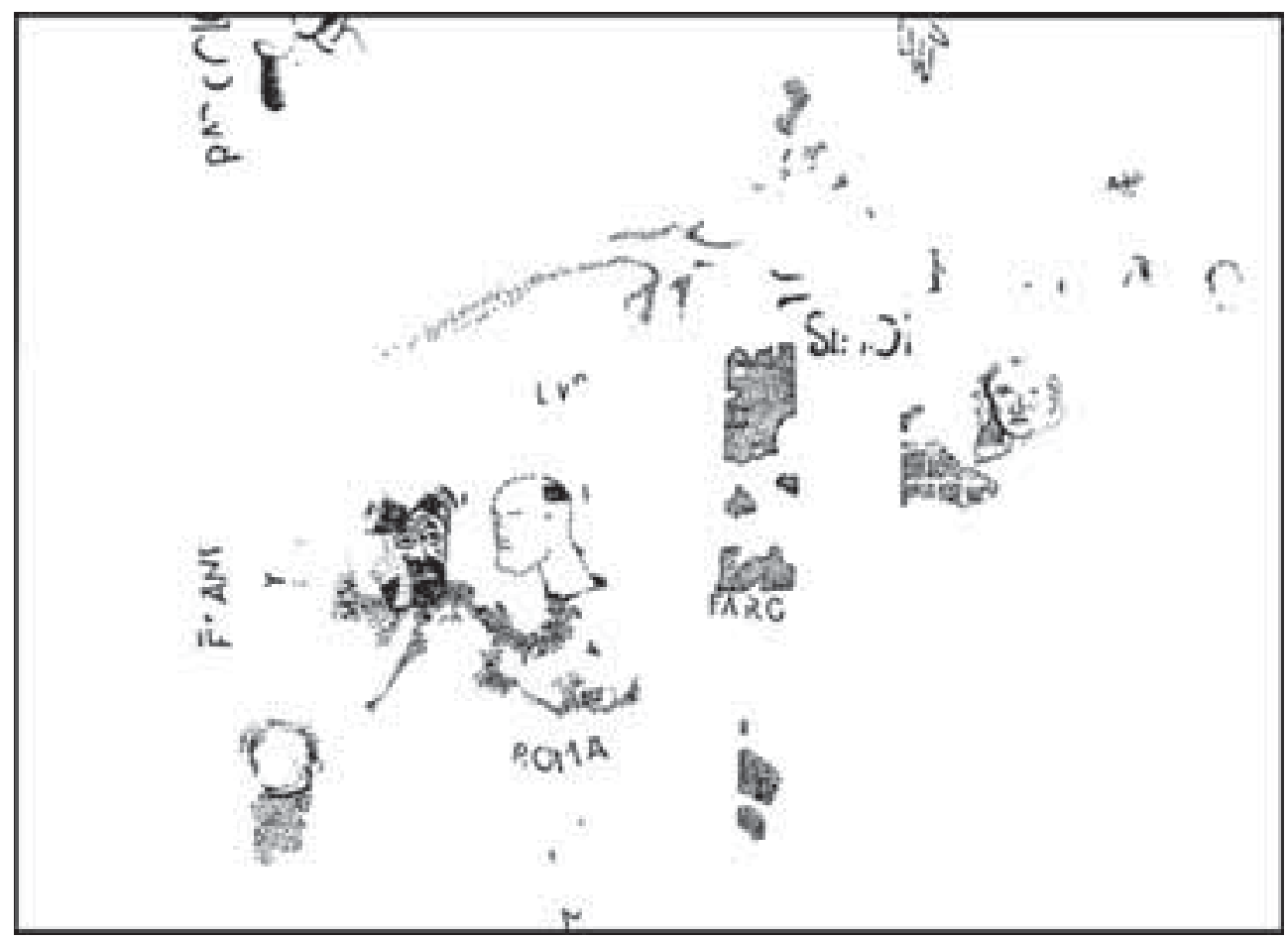

Fig. 9. Reconstrucción parcial del mapa de San Pedro de Rocas realizada por Serafín Moralejo Álvarez, "El mapa de la diáspora apostólica en San Pedro de Rocas...", Compostellanum, 31 (1986), p. 337, fig. 5 (reproducción autorizada).

a emular a los apóstoles ${ }^{65}$. Ilene H. Forsyth, quien ha sugerido una relación entre la escultura románica y la vita apostolica, afirma que las representaciones de los apóstoles en grupos o relacionándose con Cristo, esculpidos en el interior de las iglesias o en las galerías de los claustros de los monasterios, servían para inducir al monje a identificarse él mismo con los apóstoles ${ }^{66}$. Por ejemplo, gracias a la Visitatio Sepulchri de un capital del claustro de Notre-Dame de la Daurade (Toulouse) ${ }^{67}$ los monjes podían visitar la tumba de Cristo; y el machón de los discípulos de Emaús del claustro del monasterio de Santo Domingo de Silos (Burgos) que representa a Cristo como un peregrino a Santiago de Compostela, les permitía peregrinar con el Señor ${ }^{68}$ (fig. 10).

65 "Si viven del trabajo de sus manos, como nuestros primeros padres y los apóstoles, es cuando serán verdaderos monjes", en A. Linage Conde, op. cit., p. 125.

${ }^{66}$ I.H. Forsyth, "The Vita Apostolica and Romanesque Sculpture: Some Preliminary Observations", Gesta, 25:1 (1986), pp. 75-82.

67 Toulouse, Musée des Augustins.

68 Para la idea de la peregrinación espiritual a través de este relieve véase, además del artículo de Ilene H. Forsyth, O.K. Werckmeister, "The Emmaus and Thomas Pillar of the Cloister of Silos", M. PALACios (ed.), El románico en Silos: IX Centenario de la consagración de la iglesia y claustro: 1088-1988, Silos (Burgos), 


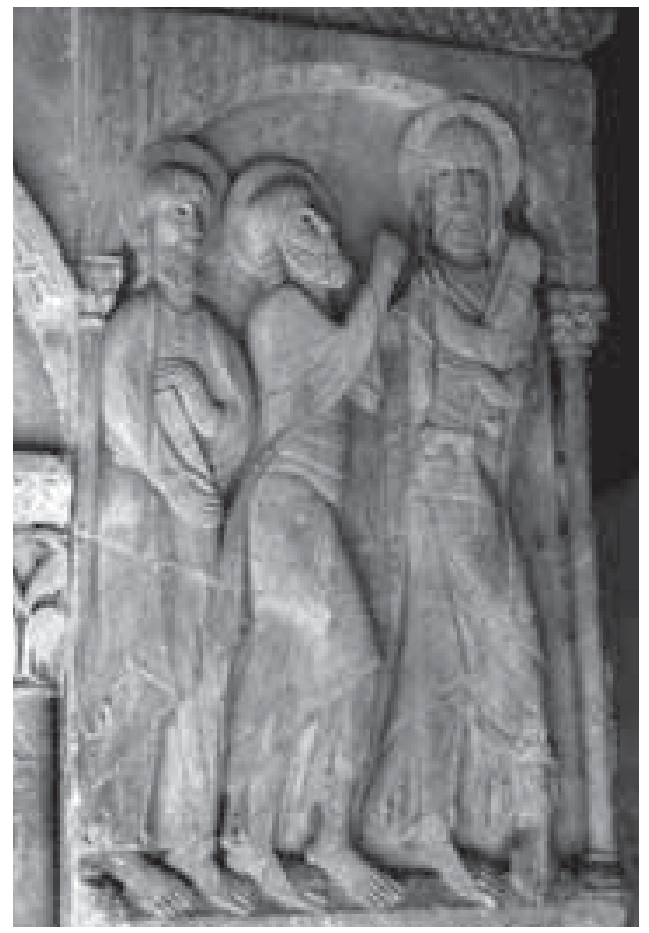

Fig. 10. Machón de los discípulos de Emaús del claustro del monasterio de Santo Domingo de Silos, Burgos (ca. 1100) (foto de la autora).

Léon Pressouyre afirma que la influencia de la vita apostolica en los programas iconográficos de los claustros no ha sido suficientemente destacada, y añade que a este respecto, el tema de los apóstoles era particularmente adecuado como motivo decorativo ${ }^{69}$. Esta misma idea podría hacerse extensiva a las artes románicas realizadas en otros medios, como es el caso de la iluminación de manuscritos o la pintura mural, y así ponerse en consonancia con los mappaemundi de Milán y San Pedro de Rocas, respectivamente. Con ello, podemos afirmar que ambos mapas copiaron un mapa de un Beato con las cabezas de los apóstoles para permitir a los monjes no solamente llevar a cabo peregrinaciones espirituales, sino también, al mismo tiempo, cumplir con la vita apostolica.

El beneficio espiritual derivado de la utilización de estos mapas podría explicarse a partir del comentario de Honorio Augustodunensis (m. ca. 1151) en su Imago Mundi, una popular enciclopedia de cosmología y geografía, combinada con una crónica de la historia del mundo, en la que su autor dice:

He representado para ti la forma de todo el mundo

para que puedas refrescar los ojos de tu cuerpo

así como los de tu corazón ${ }^{70}$.

Aunque los siglos han pasado, aún podemos disfrutar con la visión de los mapas medievales y refrescar nuestros ojos al mirarlos.

1990, pp. 149-171, esp. 159-160; J. Blaettler, “The Foot: A Monastic Metaphor at Silos”, en ibid., pp. 451464; S. Moralejo Álvarez, "El claustro de Silos y el arte de los caminos de peregrinación”, en ibid., pp. 203223, esp. 203-204; y M. PozA YAGÜE, "Cristo peregrino camino de Emaús. Un modelo de iconografía jacobea en la escultura románica hispana del siglo XII”, Memoria Ecclesiae, 18 (2001), pp. 293-315, esp. 302-306.

${ }^{69}$ L. Pressouyre, "St. Bernard to St. Francis: Monastic Ideals and Iconographic Programs in the Cloister", Gesta, 12:1/2 (1973), p. 74.

70 Traducción de la autora. "Totius orbis tibi depingi formulam / in qua sic oculum corporis valeas reficere / sicut visum cordis", en V.I.J. FLInT, "Honorius Augustodunensis Imago Mundi", Archives d'Histoire Doctrinale et Littéraire du Moyen Age, XLIX (1982), p. 48. 